\title{
Mechanisms of strontium removal by a Ba-titanate material for the wastewater
}

\section{treatment}

Célia Guévar, ${ }^{1}$ Audrey Hertz, ${ }^{* 1}$ Emmanuelle Brackx,${ }^{2}$ Yves Barré, ${ }^{1}$ Agnès Grandjean ${ }^{1}$

${ }^{1}$ CEA, DEN, DE2D, SEAD, Laboratoire des Procédés Supercritiques et de Décontamination, F30207 Bagnols-sur-Cèze, France

${ }^{2}$ CEA, DEN, DMRC, SA2I, Laboratoire de Métallographie et d'Analyse Chimique, F-30207 Bagnols-sur-Cèze, France

*Corresponding author: audrey.hertz@cea.fr, +33466397927

celia.guevar@cea.fr; yves.barre@cea.fr; agnes.grandjean@cea.fr; emmanuelle.brackx@cea.fr

Abstract - Growing interest in radioactive effluent treatment, especially after the Fukushima nuclear accident, has led to the development of new, increasingly efficient mineral sorbents. The sorbents currently attracting the most attention are materials dedicated to strontium extraction. The Ba-titanate material investigated here, combining several sorption mechanisms, has a high capacity and selectivity for strontium with a distribution coefficient, $\mathrm{K}_{\mathrm{d}}$, of $863 \mathrm{~mL} \cdot \mathrm{g}^{-1}$, obtained from a batch sorption test with seawater $\left([\mathrm{Sr}]=9 \times 10^{-5} \mathrm{~mol} \cdot \mathrm{L}^{-1}\right.$; titanate concentration, $\left.1 \mathrm{~g} \cdot \mathrm{L}^{-1}\right)$. This $\mathrm{K}_{\mathrm{d}}$ is six times higher than that of $\mathrm{Na}$-titanate, one of the strontium sorbents used for multi-nuclide removal at the Fukushima-Daiichi nuclear power station. Upon contact with the sulfate-containing effluent, $\mathrm{Sr}$ extraction proceeds by ion exchange with the Ba ions inserted in the material and by coprecipitation with insoluble barium sulfate formed at the surface of the titanate grains.

Keywords - wastewater treatment, strontium removal, titanate, coprecipitation 


\section{Introduction}

The number of studies devoted to the radioactive decontamination of wastewater has increased exponentially in the past few years in response to ever more stringent discharge standards. Among the elements present in radioactive effluents, ${ }^{90} \mathrm{Sr}$ is particularly radiotoxic because it emits high energy beta radiation and because its chemical similarity to calcium makes it attach readily to bone and bone marrow. Its half-life, 29 years, exceeds the safe timescale for decay and it must therefore be extracted from effluents. Coprecipitation is currently the most widely used method to treat effluents with low to intermediate concentrations of ${ }^{90} \mathrm{Sr}[1]$. This typically involves the formation of barium sulfate, $\mathrm{BaSO}_{4}$, from the reaction between sodium sulfate $\mathrm{Na}_{2} \mathrm{SO}_{4}$ and a barium salt $\left(\mathrm{Ba}\left(\mathrm{NO}_{3}\right)_{2}\right.$ or $\left.\mathrm{BaCl}_{2}\right)$. Strontium ions coprecipitate on the surface of barium sulfate, which is continuously renewed by crystal growth $[2,3]$. This technique is simple to implement, robust (with respect to the salinity and composition of the effluent) and cost-effective. It is also the most selective process currently available for strontium extraction with distribution coefficients in seawater of about 20000 $\mathrm{mL} \cdot \mathrm{g}^{-1}$ against $46 \mathrm{~mL} \cdot \mathrm{g}^{-1}$ for calcium for a mass/volume ratio (mass of $\mathrm{BaSO}_{4}$ / volume of seawater) of $3.5 \mathrm{~g} \cdot \mathrm{L}^{-1}[4]$. However, the drawback of this approach is that it produces large volumes of radioactive sludge. An alternative approach that produces much less waste is ion exchange in a fixed bed column. Numerous studies have already been carried out on the extraction of strontium by ion exchange with various inorganic compounds such as LTA (Linde type A) zeolites [5-9], silicotitanates [10-15] and sodium titanates [7, 16-20]. However, at typical effluent pHs (7-8), while these materials do retain strontium effectively, they are poorly selective in the presence of other alkaline earth cations (e.g. calcium) in saline solutions $[21,22]$, with, at best, strontium/calcium selectivity coefficients of around 1 to $10[12,19,21]$.

The effluents targeted in this work are the low- and intermediate-concentration radioactive by-products of nuclear activities (e.g. nuclear power plants, reprocessing plants, 
dismantling activities) or the results of nuclear accidents (such as the contaminated groundwater and seawater generated during the Fukushima-Daiichi nuclear power plant accident). These aqueous effluents are characterized by a medium to high salinity (up to 35 $\left.\mathrm{g} \cdot \mathrm{L}^{-1}\right)$, a neutral to basic $\mathrm{pH}$ (6 to 8 ), and the presence of high concentrations of alkaline and alkaline earth cations $\left(\mathrm{Na}^{+}, \mathrm{K}^{+}, \mathrm{Ca}^{2+}, \mathrm{Mg}^{2+}\right.$ and, in the case of seawater, $8 \mathrm{mg} \cdot \mathrm{L}^{-1}$ of nonradioactive $\mathrm{Sr}^{2+}$ ), various anions (chlorides, nitrates and especially sulfate ions) and traces of radioactive ${ }^{137} \mathrm{Cs}$ and ${ }^{90} \mathrm{Sr}$. The high salinity and complexity of the effluents mean that highly efficient treatment processes selective for strontium are required. We have approached this problem by coupling ion exchange and coprecipitation using an inorganic sorbent. Strontium removal has recently been demonstrated using a Ba-silicate [23] and a Ba-zeolite [24]. This paper investigates the extraction potential of a synthesized barium titanate material to complement the coprecipitation with sulfate ions present in solution. To the best of our knowledge, the chemical properties of this sorbent have not been studied before; we focus in particular on its selectivity towards strontium and the corresponding extraction mechanisms.

The sorption properties of the material were evaluated first in seawater and then in synthetic solutions, specifically by studying uptake kinetics and the effect of sulfate ions in solution. The effects of competitive cations $\left(\mathrm{Ca}^{2+}\right.$ and $\left.\mathrm{Na}^{+}\right)$on the quantities of precipitated $\mathrm{BaSO}_{4}$ and extracted strontium were assessed. X-ray diffraction (XRD), scanning electron microscopy (SEM) and nitrogen adsorption-desorption measurements were also performed to correlate the physical-chemical properties of the material with its sorbent behavior.

\section{Materials and methods}

\subsection{Reagents}

All the chemicals used in this study were supplied by Sigma Aldrich. The extraction mechanisms were studied using solutions of sodium nitrate, strontium nitrate, calcium 
chloride tetrahydrate, sodium sulfate and tetrabutylammonium sulfate. All the solutions were prepared with water with a resistivity of $15 \mathrm{M} \Omega \cdot \mathrm{cm}$.

\subsection{Synthesis}

The sodium titanate sol-gel was prepared as described in the literature [20, 25-27]. Titanium isopropoxide $(25 \mathrm{~g}$ ) was added rapidly to $27.2 \mathrm{~g}$ of a $50 \mathrm{wt} \%$ solution of $\mathrm{NaOH}$ before $20 \mathrm{~mL}$ of deionized water was added. This mixture was transferred to a Teflon vessel for hydrothermal pressure treatment. Heat treatment was performed at $160{ }^{\circ} \mathrm{C}$ for $22 \mathrm{~h}$ under autogenous pressure. The resulting gel was filtered, washed with deionized water to remove excess $\mathrm{NaOH}$ and dried at $80^{\circ} \mathrm{C}$ for $24 \mathrm{~h}$. The total Na content of the material was $3.70 \pm 0.74$ $\mathrm{mmol} \cdot \mathrm{g}^{-1}$. The barium titanate sorbent was prepared by substituting the $\mathrm{Na}$ in Na-titanate $\left(\mathrm{Na}_{4} \mathrm{Ti}_{9} \mathrm{O}_{20}\right)$ with $\mathrm{Ba}$. $\mathrm{Na}_{4} \mathrm{Ti}_{9} \mathrm{O}_{20}$ powder was mixed in a $1 \mathrm{~mol} \cdot \mathrm{L}^{-1} \mathrm{BaCl}_{2} \cdot 2 \mathrm{H}_{2} \mathrm{O}$ solution for $24 \mathrm{~h}$ at a mass concentration of $1 \mathrm{~g}$ per $15 \mathrm{~mL}$. The resulting Ba-titanate was then washed with distilled water and dried at $80^{\circ} \mathrm{C}$ for $16 \mathrm{~h}$.

\subsection{Characterization}

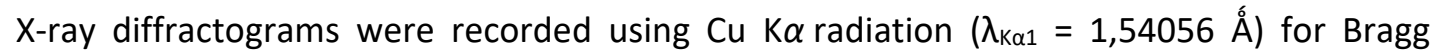
angles (20) varied between 5 and $70^{\circ}$ at $0.01275^{\circ} \cdot \mathrm{min}^{-1}$ on a Panalytical $X^{\prime}$ Pert Pro powder device equipped with a Xcelerator type detector and operated at $45 \mathrm{kV}$ and $40 \mathrm{~mA}$. A Rietveld refinement was performed to calculate the cell parameters of the $\mathrm{Ba}_{(1-\mathrm{x})} \mathrm{Sr}_{\mathrm{x}} \mathrm{SO}_{4}$ precipitates using the initial structure determined by Goldish for $\mathrm{Ba}_{0.75} \mathrm{Sr}_{0.25} \mathrm{SO}_{4}$ [28]. The barium and strontium contents of the $\mathrm{Ba}_{(1-x)} \mathrm{Sr}_{x} \mathrm{SO}_{4}$ precipitates were then deduced from the space group (Pbnm) and the calculated unit-cell parameters thanks to the relation between the latter and the composition of $\mathrm{Ba}_{x} \mathrm{Sr}_{1-x} \mathrm{SO}_{4}$ powders published by Sitepu and Zaidi [29]. 
The specific surface area, pore size and pore volume of the Ba-titanate were measured by nitrogen adsorption-desorption analysis. The sample was degassed at $200{ }^{\circ} \mathrm{C}$ for $24 \mathrm{~h}$ before measurements were taken at $77 \mathrm{~K}$ using a Micrometrics ASAP 2020 analyzer.

Scanning electron micrographs and maps in chemical contrast were obtained using a Carl Zeiss MERLIN device equipped with an $80 \mathrm{~mm}^{2}$ Oxford Instruments X-MAX energy-dispersive Xray analyzer (SEM-EDX). The samples were embedded in a non-conductive epoxy resin, polished using a GATAN Ilion+ cross-polisher and metallized with gold.

Size distribution of the Ba-titanate was determined by laser diffraction using a Malvern Mastersizer device. A suspension of Ba-titanate was prepared in distilled water and ultrasonication was applied to disperse the material before and during analysis.

Inductively Coupled Plasma Atomic Emission Spectrometry (ICP-AES), Thermo Fisher Scientific iCAP $7400 \mathrm{DV}$, was used to determine the ion contents $\left(\mathrm{Na}^{+} / \mathrm{Ca}^{2+} / \mathrm{Ba}^{2+} / \mathrm{Sr}^{2+} / \mathrm{S}\right)$ of the solutions used for the sorption experiments after dilution in $2 \%$ nitric acid. The sulfate concentrations were calculated from the sulphur concentrations obtained by ICP-AES. Three replicate measurements were performed for each sample. To determine the chemical composition of the solids, $30 \mathrm{mg}$ of each sample was mineralized by dissolution in hot $\mathrm{HNO}_{3} / \mathrm{HF}$. The $\mathrm{Na}, \mathrm{Ba}$ and $\mathrm{Ti}$ contents of the resulting solutions were measured by ICP-AES with estimated uncertainties of the order of $20 \%$.

\subsection{Decontamination efficiency}

The decontamination efficiency of the materials was evaluated as follows. The sorption capacity was calculated using Eq. (1): 
$Q_{t}=\left(C_{0}-C_{t}\right) \times V / m$

where $Q_{t}$ is the sorption capacity of the sorbent at time $t$ and $Q_{e}$ is the sorption capacity at equilibrium ( $\mathrm{mg} \cdot \mathrm{g}^{-1}$ or $\mathrm{meq} \cdot \mathrm{g}^{-1}$ of titanate); $C_{0}$ and $C_{t}$ are respectively the initial and equilibrium concentration of the component $\left(\mathrm{mg} \cdot \mathrm{L}^{-1}\right.$ or $\left.\mathrm{meq} \cdot \mathrm{L}^{-1}\right) ; V$ is the volume of the solution (L); and $m$ is the mass of the sorbent (g).

Distribution coefficients, $\mathrm{K}_{d}\left(\mathrm{~mL} \cdot \mathrm{g}^{-1}\right)$, for different ion-sorbent combinations were calculated using Eq. (2),

$K_{d}=Q / C_{e} \times 1000$

with high values indicating that the sorbent has a high affinity for the ion. $K_{d}$ is constant at trace concentrations of the studied ion. The selectivity of the prepared Ba-titanate for Sr over Ca in the effluent was then calculated from the $K_{d}$ ratio,

$s K_{C a}^{S r}=K_{d}(S r) / K_{d}(C a)$

with higher values indicating a greater selectivity.

Lastly, the decontamination efficiency was quantified using the decontamination factor (DF), the parameter commonly used in the nuclear industry:

$\mathrm{DF}=[\mathrm{Sr}]_{\text {initial }} /[\mathrm{Sr}]_{\text {final }}$

For strontium decontamination, the target is usually a DF value of 100 (corresponding to the extraction of $99 \%$ of the $\mathrm{Sr}$ in solution).

\subsection{Extraction tests}

Strontium extraction tests were performed on solutions containing $1 \mathrm{~g} \cdot \mathrm{L}^{-1}$ sorbent. The experiments were carried out in batch mode under stirring at ambient temperature in $60 \mathrm{~mL}$ 
polypropylene vials. The precipitation or extraction kinetics were measured by placing $20 \mathrm{mg}$ of the sorbent in contact with $20 \mathrm{~mL}$ of each solution for $5 \mathrm{~min}$ to $24 \mathrm{~h}$, with a separate experiment performed for each duration.

The remaining extraction experiments were performed for $3 \mathrm{~h}$ under stirring. All solutions were filtered using a $0.2 \mu \mathrm{m}$ syringe filter. The extraction capacity, $Q_{t}$, was calculated from the measured initial and final Sr concentrations using Eq. (1). These values were also used to calculate the distribution coefficient at a given point in time. The sulfate concentrations measured in solution were used to calculate the concentration of the barium sulfate precipitates. To compare the amounts of Ba released in solution with the amounts of the ions sorbed in/on the solid, the concentrations were expressed as equivalent weights of each species per gram of Ba-titanate $\left(\mathrm{meq} \cdot \mathrm{g}^{-1}\right)$.

\subsubsection{Extraction tests in seawater}

The Ba-titanate and Na-titanate sorbents $\left(1 \mathrm{~g} \cdot \mathrm{L}^{-1}\right)$ were placed in seawater (from the English Channel) for $3 \mathrm{~h}$ under stirring. The composition of the seawater used is given in Table 1.

\section{Table 1}

Cationic and anionic composition of the seawater used for extraction experiments $( \pm 10 \%)$.

\begin{tabular}{lcccccc}
\hline Cations & $\mathrm{Sr}^{2+}$ & $\mathrm{Cs}^{+}$ & $\mathbf{N a}^{+}$ & $\mathrm{Mg}^{2+}$ & $\mathrm{Ca}^{2+}$ & $\mathrm{K}^{+}$ \\
\hline (mg $\left.\cdot \mathrm{L}^{-1}\right)$ & 7.1 & $<0.01$ & 12842 & 1376 & 444 & 480 \\
\hline \hline Anions & $\mathrm{Cl}^{-}$ & $\mathrm{F}^{-}$ & $\mathrm{Br}^{-}$ & $\mathbf{S O}_{4}{ }^{-2}$ & $\mathrm{NO}^{-}$ & $\mathrm{HCO}_{3}{ }^{-}$ \\
\hline (mg $\left.\cdot \mathrm{L}^{-1}\right)$ & 19000 & 0.56 & 66.3 & 2700 & $<1$ & 142 \\
\hline
\end{tabular}

\subsubsection{Study of the extraction mechanisms}

The extraction mechanisms with the Ba-titanate were studied using several solutions whose compositions are listed in Table 2 . The extraction capacity and the affinity of the Batitanate for $\mathrm{Sr}$ were measured in distilled water with $10^{-4} \mathrm{~mol} \cdot \mathrm{L}^{-1} \mathrm{Sr}$ (Sol1). Two other 
experiments were performed on solutions containing a mix of $\mathrm{Sr}$ and $\mathrm{Na}$ (Sol2) or of $\mathrm{Sr}, \mathrm{Na}$ and $\mathrm{Ca}(\mathrm{Sol} 3$ ) to evaluate the respective effects of $\mathrm{Na}$ and $\mathrm{Ca}$ on $\mathrm{Sr}$ extraction in distilled water.

Further experiments were performed on solutions with the same sulfate concentration as seawater $\left(2.8 \times 10^{-2} \mathrm{~mol} \cdot \mathrm{L}^{-1}\right.$, Sol4-7, Table 2$)$. The kinetics of $\mathrm{BaSO}_{4}$ precipitation at the surface of the Ba-titanate was studied in the solution containing $\mathrm{Na}_{2} \mathrm{SO}_{4}$ only (Sol4). The role of $\mathrm{Na}$ ions in this process were clarified by repeating the experiments in a solution of tetrabutylammonium sulfate (Sol5). Experiments were also performed on a solution containing $\mathrm{Sr}, \mathrm{Na}$ and sulfates (Sol6) in comparison with those performed on the equivalent solution without sulfates (Sol2), to determine the effect of sulfates on the $\mathrm{Sr}$ and $\mathrm{Na}$ extraction capacities of the sorbent. Lastly, the influence of $\mathrm{Ca}$ on $\mathrm{BaSO}_{4}$ precipitation and $\mathrm{Sr}$ extraction with this material was investigated by comparing the results obtained with solutions Sol6 and Sol7, the latter containing additional $\mathrm{Ca}$.

Table 2

Composition of the solutions used to determine the extraction mechanisms of the Ba-titanate sorbent.

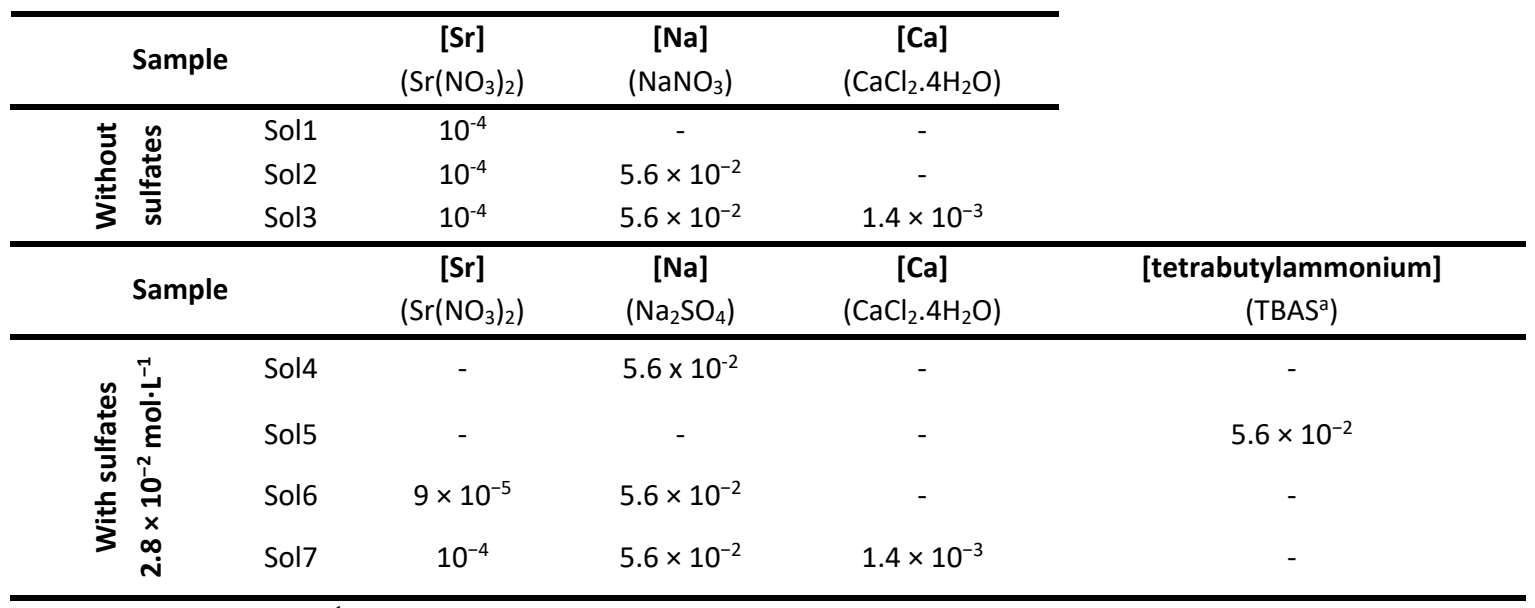

All contents given in $\mathrm{mol} \cdot \mathrm{L}^{-1}$

atetrabutylammonium sulfate

\section{Results and discussion}

\subsection{Characterization of the synthesized powder samples}


The powder XRD curves obtained for the $\mathrm{Na}$ - and Ba-titanate materials are shown in Fig. 1. The two diffraction patterns are typical of a pure sodium titanate material [27] with four diffraction lines at $2 \theta=9.5^{\circ}\left(10^{\circ}\right.$ for the Na-titanate), $24^{\circ}, 28^{\circ}$ and $48^{\circ}$. The broad lines indicate that the two materials have a low crystallinity. The pattern for the Ba-titanate is weaker because barium ions absorb $\mathrm{Cu} \mathrm{K} \alpha \mathrm{X}$-rays [30]. Assuming that the Ba- and Na-titanates have the same multilayered structure, the first reflection at $10^{\circ}$ for the Na-titanate and $9.5^{\circ}$ for the Ba-titanate can be attributed to interlayer diffraction, and the corresponding distances ( 9 and $9.31 \AA$ respectively) then indicate that $\mathrm{Na} / \mathrm{Ba}$ ion-exchange in this material leads to a slight increase in the interlayer spacing.

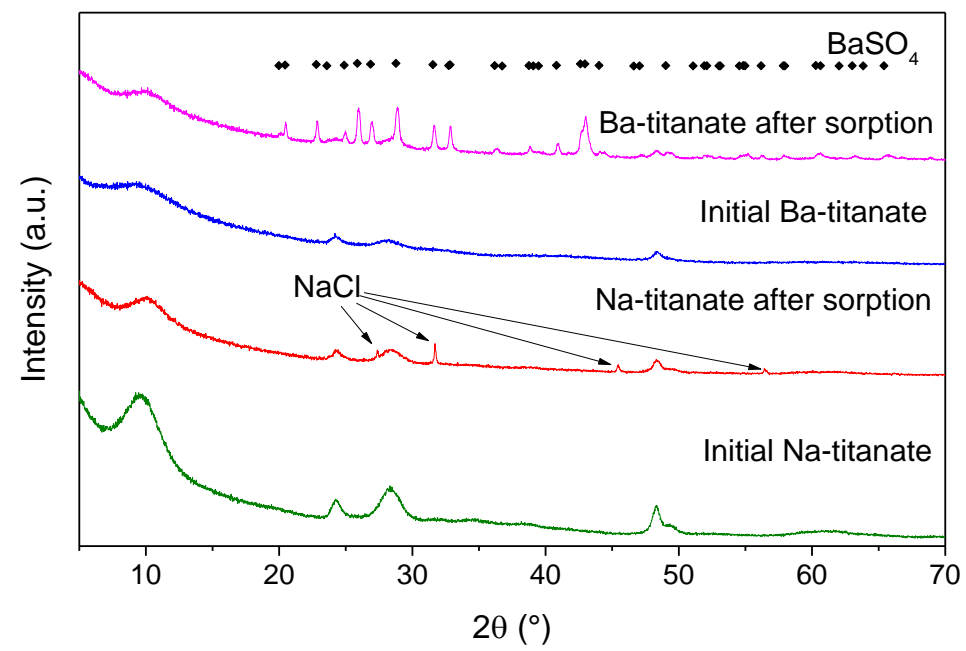

Fig. 1. Powder X-ray diffractograms of the sorbents before and after contact with seawater.

The SEM data in Fig. 2 show that both materials have a non-specific grain morphology. The grains vary in size from 10 to $1300 \mu \mathrm{m}$, as confirmed by laser scattering measurements (Fig. S1). 

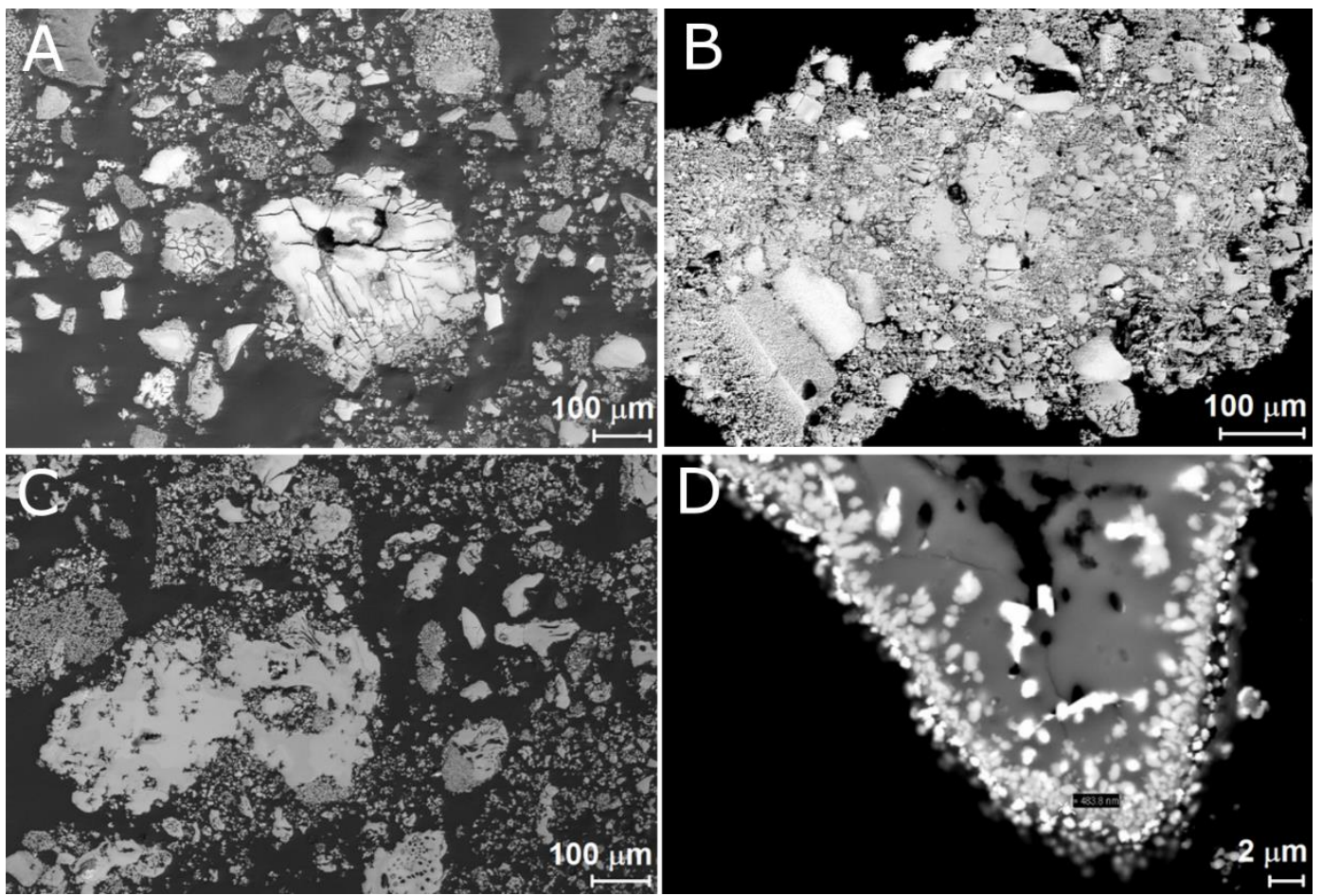

Fig. 2. Scanning electron micrographs (back-scattered electrons) of $(A, B)$ the $\mathrm{Na}$ - and $(C, D)$ the Ba-titanate sorbent $(A, C)$ before and $(B, D)$ after contact with seawater $\left(m / V=1 \mathrm{~g} \cdot \mathrm{L}^{-1}\right)$.

Elemental analyses of these two materials yielded compositions of $\mathrm{Na}_{3.5} \mathrm{Ti}_{9} \mathrm{O}_{19.8} \cdot \mathrm{H}_{2} \mathrm{O}$ and $\mathrm{Ba}_{2.17} \mathrm{Na}_{0.33} \mathrm{Ti}_{9} \mathrm{O}_{20.3} \cdot \mathrm{H}_{2} \mathrm{O}$. These compositions are respectively close to the theoretical compositions of pure sodium titanate $\left(\mathrm{Na}_{4} \mathrm{Ti}_{9} \mathrm{O}_{20}\right)$ and pure barium titanate $\left(\mathrm{Ba}_{2} \mathrm{Ti}_{9} \mathrm{O}_{20}\right)$. These measurements point out that the cation exchange capacity of the Na-titanate $\left(\mathrm{CEC}_{\mathrm{Na}}\right)$ is equal to $3.7 \pm 0.4$ meq Na per gram of titanate. Likewise, the Ba-titanate contains $4.0 \pm 0.8$ meq Ba per gram of titanate and its residual $\mathrm{Na}$ concentration is $0.3 \pm 0.1 \mathrm{meq} \cdot \mathrm{g}^{-1}$. The cation exchange capacity of the Ba-titanate $\left(\mathrm{CEC}_{\mathrm{Ba}}\right)$ is therefore $4.0 \pm 0.8$ meq Ba per gram of titanate. Given the $20 \%$ error in the measured barium concentration, two extreme cation exchange capacities were defined: $\mathrm{CEC}_{\mathrm{Ba}} \mathrm{min} .=3.2 \mathrm{meq} \cdot \mathrm{g}^{-1}$ and $\mathrm{CEC}_{\mathrm{Ba}} \mathrm{max} .=4.8 \mathrm{meq} \cdot \mathrm{g}^{-1}$. However, $\mathrm{CEC}_{\mathrm{Ba}}$ cannot be higher than $\mathrm{CEC}_{\mathrm{Na}}\left(3.7 \mathrm{meq} \cdot \mathrm{g}^{-1}\right)$, the exchange capacity of the Natitanate from which the Ba-titanate was synthesized by ion-exchange (as described in the methods section). 
The Ba-titanate sorbent was found to have a specific surface area of $154 \mathrm{~m}^{2} \cdot \mathrm{g}^{-1}$ (according to the model of Brunauer, Emmett and Teller), a mean pore size diameter of $4 \mathrm{~nm}$ (method of Barrett, Joyner and Halenda), and a maximal pore volume of $0.19 \mathrm{~cm}^{3} \cdot \mathrm{g}^{-1}$. Its adsorption isotherm (Fig. S2, IUPAC type IV) is characteristic of mesoporous materials. The hysteresis loop may be the result of capillary condensation in the mesopores between aggregated titanate grains.

\subsection{Sorption tests in seawater}

The distribution coefficients for strontium, $\mathrm{K}_{d}(\mathrm{Sr})$, obtained after stirring the Na-titanate and Ba-titanate samples in seawater for $3 \mathrm{~h}$, were respectively $154 \mathrm{~mL} \cdot \mathrm{g}^{-1}$ and $863 \mathrm{~mL} \cdot \mathrm{g}^{-1}$. While the microstructure of the Na-titanate powder seems unaffected by the Sr extraction test in seawater (Fig. 2A, B), the SEM image of the Ba-titanate after contact with seawater (Fig. 2D) reveals two separate phases that respectively appear grey and white in the images. The grey phase corresponds to the titanate grains, while the EDX chemical maps in Fig. 3 show that sulphur and oxygen are localized in the white phase, meaning that this is sulfate-enriched. The emission lines of $\mathrm{Ba}$ and $\mathrm{Ti}$ overlap ( $\mathrm{Ti}_{\mathrm{K} \alpha} 4.508 \mathrm{keV}$ and $\mathrm{Ba}_{\llcorner\alpha} 4.465 \mathrm{keV}$ ), precluding quantitative analysis and the recording of distribution maps. However, comparing the Ba emission line intensities at $5.2 \mathrm{keV}$ (decorrelated from Ti) in the EDX spectra of the titanate and the sulphur phase shows that barium is present in the latter but not in the former (see Fig. S3). The sulphur phase is not observed in the initial Ba-titanate powder (Fig. 2C), nor does it form in the Natitanate material. The sulphur phase must therefore form during contact between the Ba ions (in the Ba-titanate sorbent) and seawater. Note lastly that Fig. $3 \mathrm{E}$ shows that Sr ions are present both in the sulphur phase and in the titanate grains. 

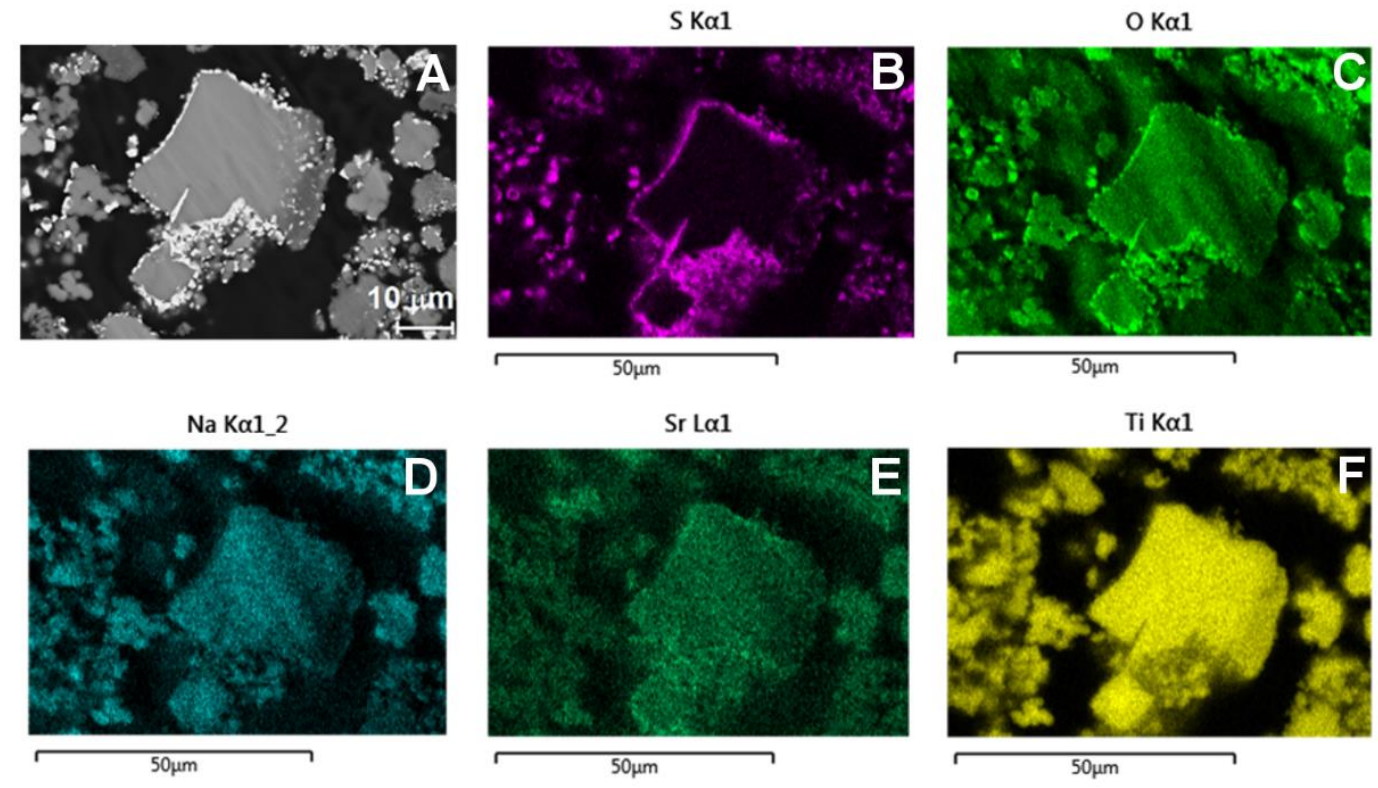

Fig. 3. EDX chemical maps of the Ba-titanate sorbent after contact with seawater: $(A)$ the corresponding scanning

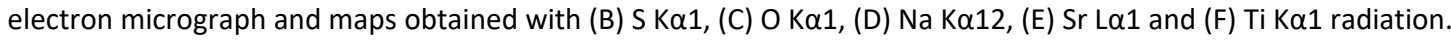

In addition to the titanate phase, the XRD pattern of the Ba-titanate sample collected after contact with seawater (Fig. 1) reveals the presence of a crystallized barite $\left(\mathrm{BaSO}_{4}\right)$ phase. There is no evidence of this phase in the corresponding data for the Na-titanate (initial and after sorption) or initial Ba-titanate materials. These results indicate that the crystals observed by SEM on the surface of the Ba-titanate grains correspond to barite that presumably precipitates upon contact between the Ba ions in the sorbent and sulfate ions in the seawater.

To sum up, the Ba-titanate sorbent removes strontium from seawater more effectively than the Na-titanate does. This seems to be due to the precipitation of barium sulfate crystals at the surface of the titanate grains upon contact between the $\mathrm{Ba}^{2+}$ ions in the titanate and sulfate ions in the seawater.

\subsection{Extraction mechanisms}

\subsubsection{Behavior in distilled water}


The results of the sorption experiments performed on solutions Sol1-7 are summarized in Fig. 4. In Fig. 4A, the concentrations of Ba released in solution are compared to those of $\mathrm{Sr}, \mathrm{Na}$ and $\mathrm{Ca}$ sorbed in the solid during contact between the Ba-titanate material and solutions containing $\mathrm{Sr}$ (Sol1 in Table 2), Sr and $\mathrm{Na}$ (Sol2) or Sr, $\mathrm{Ca}$ and $\mathrm{Na}$ (Sol3). In Fig. 4B, the concentrations of precipitated $\mathrm{SO}_{4}$ are compared to those of $\mathrm{Sr}, \mathrm{Na}$ and $\mathrm{Ca}$ sorbed in the solid during contact between the Ba-titanate material and solutions containing sulfates, $\mathrm{Sr}$ and $\mathrm{Na}$ (Sol6) or sulfates, $\mathrm{Sr}, \mathrm{Na}$ and $\mathrm{Ca}$ (Sol7).
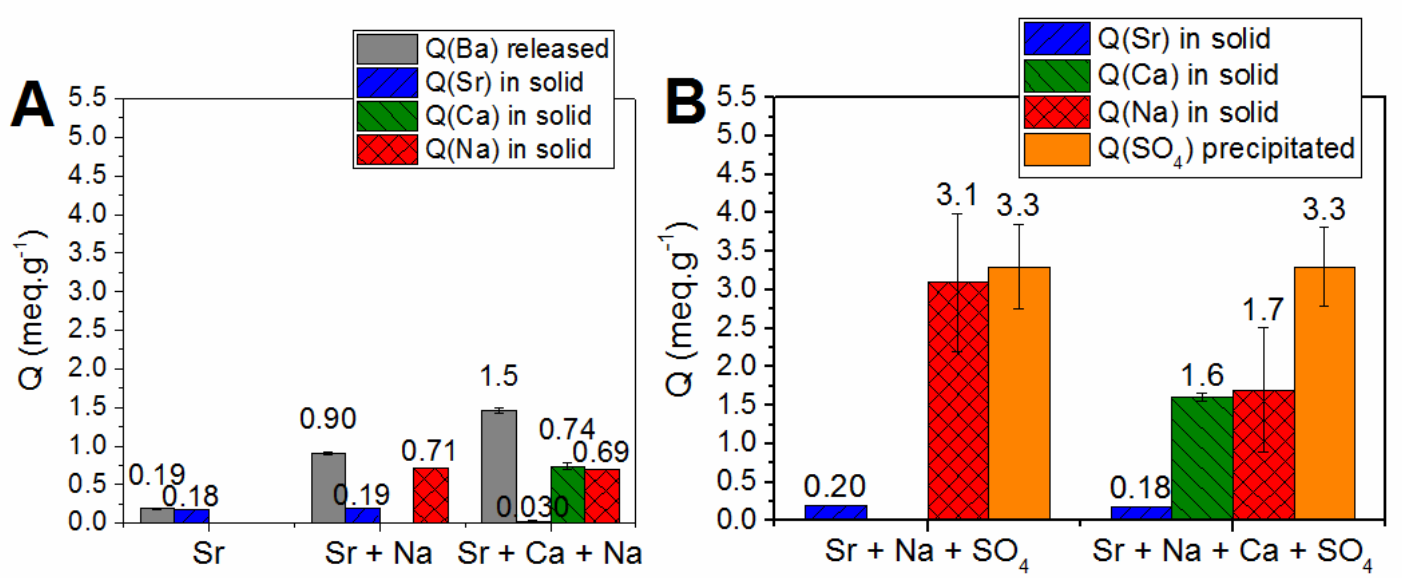

Fig. 4. Results of sorption experiments performed on solutions Sol1-7 (see Table 2) (A) without sulfate ions, (B) with $2.8 \times 10^{-2} \mathrm{~mol} \cdot \mathrm{L}^{-1}$ sulfate ions.

\subsubsection{Behavior in distilled water containing Sr without sulfate ions (Sol1)}

The ion-exchange reaction between Ba from the solid and $\mathrm{Sr}$ from the solution was studied using the $\operatorname{Sr}\left(\mathrm{NO}_{3}\right)_{2}$ Sol1 solution (without sulfate). The amount of Ba released from the solid $\left(0.19 \mathrm{meq} \cdot \mathrm{g}^{-1}\right)$ matches the amount of $\mathrm{Sr}$ extracted from the solution $\left(0.18 \mathrm{meq} \cdot \mathrm{g}^{-1}\right)$, considering the $\pm 0.005 \mathrm{meq} \cdot \mathrm{g}^{-1}$ analytical uncertainties. This implies that a pure ion-exchange mechanism is involved, as described by Eq. (5), 
$\overline{B a^{2+}}+S r^{2+} \rightleftharpoons \overline{S r^{2+}}+B a^{2+}$

where $\mathrm{Ba}^{2+}$ and $\mathrm{Sr}^{2+}$ are ions in solution and $\overline{\mathrm{Ba}^{2+}}$ and $\overline{\mathrm{Sr}^{2+}}$ are ions in the solid.

3.3.1.2. $\quad$ Behavior in distilled water containing $\mathrm{Sr}$ and Na without sulfate ions (Sol2)

In solution Sol2, Ba from the solid may exchange with both Sr (Eq. (5)) and $\mathrm{Na}$ (Eq. (6)) from the solution. Fig. 4A shows that the concentration of Ba ions released $\left(0.90 \mathrm{meq} \cdot \mathrm{g}^{-1}\right)$ from the solid after contact with a solution containing both $\operatorname{Sr}\left(10^{-4} \mathrm{~mol} \cdot \mathrm{L}^{-1}\right)$ and $\mathrm{Na}\left(5.6 \times 10^{-2}\right.$ $\left.\mathrm{mol} \cdot \mathrm{L}^{-1}\right)$ is higher than after contact with a solution containing only $10^{-4} \mathrm{~mol} \cdot \mathrm{L}^{-1} \mathrm{Sr}(0.19$ meq $\left.\cdot \mathrm{g}^{-1}\right)$. Interestingly, the quantity of $\mathrm{Sr}$ sorbed by the solid is the same $\left(0.19 \mathrm{meq} \cdot \mathrm{g}^{-1}\right)$ whether $\mathrm{Na}$ is present in the solution or not. In other words, the amount of Ba released in solution is higher than the amount of Sr sorbed by the titanate. Measuring slight variations in these high Na concentrations by ICP-AES was not possible. Nonetheless, even without direct information on the amount of Na sorbed by the solid, this can be deduced from the difference between the amounts of $\mathrm{Ba}$ and $\mathrm{Sr}$ respectively released and sorbed by the solid $\left(0.71 \mathrm{meq} \cdot \mathrm{g}^{-1}\right)$ via $Q(B a)_{\text {released }}=[Q(S r)+Q(N a)]_{\text {sorbed, }}$ yielding the following exchange reaction:

$\overline{B a^{2+}}+2 N a^{+} \rightleftharpoons 2 \overline{N a^{+}}+B a^{2+}$

\subsubsection{Behavior in distilled water containing Sr, Na and Ca without sulfate ions} (Sol3)

Similarly, extraction in the solution containing $\mathrm{Sr}, \mathrm{Na}$ and $\mathrm{Ca}$ in distilled water, without sulfate ions, can only occur by ion-exchange (Eqs (5), (6) and (7)). In this case, Fig. 4A shows that the $\mathrm{Sr}$ extraction capacity falls to $0.030 \mathrm{meq} \cdot \mathrm{g}^{-1}$ because of the competitive sorption of $\mathrm{Ca}$ $\left(0.74 \mathrm{meq} \cdot \mathrm{g}^{-1}\right)$. As explained in the preceding paragraph, the Na concentrations could not be measured precisely in these solutions. However, considering the material balance, the amount 
of $\mathrm{Ba}$ released in solution $\left(1.5 \mathrm{meq} \cdot \mathrm{g}^{-1}\right)$ must correspond to the amounts of $\mathrm{Sr}$, $\mathrm{Ca}$ and $\mathrm{Na}$ sorbed by the titanate, and thus the amount of $\mathrm{Na}$ extracted must be roughly $0.69 \mathrm{meq} \cdot \mathrm{g}^{-1}$. Table 3 shows that the $K_{d} S$ of $\mathrm{Sr}$ and Ca calculated from these results are similar, which means that the selectivity coefficient $s K_{C a}^{S r}$ is close to 1 . The Ba-titanate is not selective for Sr over Ca but sorbs both these species more readily than $\mathrm{Na}$. The main exchange reaction in solution Sol3 is therefore:

$\overline{\mathrm{Ba}^{2+}}+\mathrm{Ca}^{2+} \rightleftharpoons \overline{\mathrm{Ca}}+\mathrm{Ba}^{2+}$

In summary, $\mathrm{Na}$ ions at concentrations up to $5.6 \times 10^{-2} \mathrm{~mol} \cdot \mathrm{L}^{-1}$ do not disturb the $\mathrm{Sr}$ sorption process with the Ba-titanate material (because the titanate has a higher affinity for $\mathrm{Sr}$ than $\mathrm{Na}$ ) but enable the release of larger quantities of Ba ions than in solutions containing only Sr ions. Ca ions also increase the amount of Ba released (versus solutions containing only Sr or both $\mathrm{Sr}$ and $\mathrm{Na})$, but at a much lower concentration $\left(1.4 \times 10^{-3} \mathrm{~mol} \cdot \mathrm{L}^{-1}\right)$. However, the competitive sorption of Ca decreases the material's sorption capacity for Sr.

Table 3

Distribution coefficients $\left(K_{d}\right)$, selectivity coefficients $\left(s K_{C a}^{S r}\right)$ and decontamination factors (DF) for the Ba-titanate sorbent in solutions containing or not sulfate ions.

\begin{tabular}{lcc} 
Solution & Sol3 (without sulfate) & Sol7 (with sulfate) \\
\hline $\mathrm{K}_{\mathrm{d}}(\mathrm{Sr})\left(\mathrm{mL} \cdot \mathrm{g}^{-1}\right)$ & 330 & 86854 \\
$\mathrm{~K}_{\mathrm{d}}(\mathrm{Ca})\left(\mathrm{mL} \cdot \mathrm{g}^{-1}\right)$ & 396 & 1451 \\
$\boldsymbol{S} \boldsymbol{K}_{\boldsymbol{C a}}^{\boldsymbol{r} \boldsymbol{a}}$ & 1 & 60 \\
$\mathrm{DF}$ & 1 & 94 \\
\hline
\end{tabular}

\subsubsection{Behavior in sulfate solutions}

\subsubsection{Behavior in a solution containing $\mathrm{Na}$ and sulfate ions (Sol4)}

The behavior of the Ba-titanate sorbent in a sodium sulfate solution was studied by measuring the concentrations of $\mathrm{Na}, \mathrm{Ba}$ and $\mathrm{SO}_{4}$ ions before and after contact with the solid 
for different contact times (Fig. 5). The sorbent was also characterized by XRD after contact periods of $10 \mathrm{~min}, 1 \mathrm{~h}$ and $24 \mathrm{~h}$ (Fig. S4).

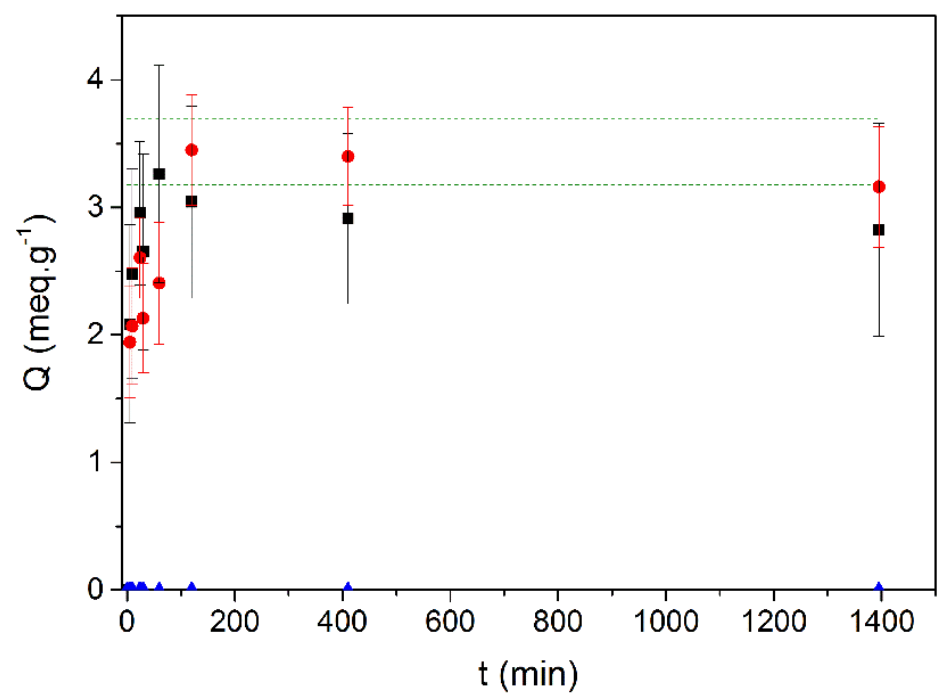

Fig. 5. Extraction behavior of the Ba-titanate in solutions containing $\mathrm{Na}$ and sulfate ions. Amounts (Q) of $\mathrm{SO}_{4}{ }^{2-}$ precipitated (red), $\mathrm{Na}^{+}$sorbed (black) and $\mathrm{Ba}^{2+}$ released (blue) versus contact time between the $\mathrm{Ba}$-titanate and a $2.8 \times 10^{-2} \mathrm{~mol} \cdot \mathrm{L}^{-1}$ sodium sulfate solution (Sol4 in Table 2 ). The minimum and maximum estimated cation exchange capacity of the Ba-titanate sorbent are represented by dotted lines.

Regardless of the contact time, the Ba concentration remains below the detection limit, implying that the $\mathrm{Ba}^{2+}$ ions either remain in the titanate or all precipitate. On the other hand, Fig. 5 shows that the sorption capacity for sulfate ions (see Eq. (1)) is high-meaning that these are extracted from the solution-and similar to the expected exchange capacity of the Ba-titanate. The XRD data obtained after contact reveal a crystalline $\mathrm{BaSO}_{4}$ phase. These results suggest therefore that sorbed sulfate ions react with $\mathrm{Ba}$ ions from the solid and precipitate as barium sulfate. Assuming that the amount of precipitated sulfate ions equals (in meq. $\mathrm{g}^{-1}$ ) the amount of barium sulfate formed in the solid, the variation as a function of time of the concentration of sulfate ions in solution reveals the kinetics of $\mathrm{BaSO}_{4}$ precipitation. All the typical $\mathrm{BaSO}_{4}$ diffraction peaks are already present after just 10 min of contact with the 
sulfate solution (Fig. S4). This confirms that $\mathrm{BaSO}_{4}$ precipitation occurs from the very first minutes of contact between the Ba-titanate and the sulfate solution. After $2 \mathrm{~h}$, the amount of precipitated sulfate reaches $3.4 \mathrm{meq} \cdot \mathrm{g}^{-1}$.

Interestingly, Fig. 5 shows that the amount of $\mathrm{Na}$ ions sorbed in the titanate is the same as the amount of $\mathrm{BaSO}_{4}$ precipitated, which can be attributed to ion exchange between $\mathrm{Ba}$ ions from the solid and $\mathrm{Na}$ ions from the solution. In a distilled water solution containing only $\mathrm{Na}$ ions $\left(2.2 \times 10^{-2} \mathrm{~mol} \cdot \mathrm{L}^{-1}\right)$, the amount of Ba released is very low $\left(0.56 \mathrm{meq} \cdot \mathrm{g}^{-1}\right)$. One can therefore conclude that the shift of the ion exchange equilibrium toward the incorporation of $\mathrm{Na}$ ions in the titanate and release of $\mathrm{Ba}$ ions into the solution is due to the presence of sulfate ions.

To sum up, in a solution containing only sodium sulfate and the Ba-titanate powder, $\mathrm{Na}$ ions from the solution exchange with all the $\mathrm{Ba}$ ions from the solid. $\mathrm{BaSO}_{4}$ then precipitates rapidly as the Ba released from the solid reacts with sulfate ions in the solution. All the Ba ions precipitate within $2 \mathrm{~h}$. The sorption kinetics for $\mathrm{Na}$ ions are identical to those of $\mathrm{BaSO}_{4}$ precipitation, suggesting that the latter is controlled by the $\mathrm{Ba} / \mathrm{Na}$ ion exchange process.

\subsubsection{Behavior in a solution containing tetrabutylammonium sulfate (Sol5)}

The behavior of the Ba-titanate sorbent in contact with a tetrabutylammonium sulfate solution was investigated by tracking the amounts of released $\mathrm{Ba}$ and precipitated $\mathrm{SO}_{4}$ ions as a function of the contact time (Fig. 6). Again, the Ba concentration in solution remains below the detection limit for all contact times, indicating that the $\mathrm{Ba}^{2+}$ ions either remain in the titanate or precipitate rapidly with sulfate ions and are therefore not detected in solution by ICP-AES. However, Fig. 6 shows that only a negligible amount of sulfate precipitates $(<0.5$ meq $\cdot \mathrm{g}^{-1}$ ), which implies that the Ba ions located in the titanate do not precipitate with sulfates in solution. This is expected because tetrabutylammonium cations are too bulky to fit between 
the titanate layers and move the $\mathrm{Ba}$ ions into the solution. This experiment underlines the essential role of $\mathrm{Na}$ ions in the $\mathrm{BaSO}_{4}$ precipitation mechanism. Cations in solution able to exchange with the $\mathrm{Ba}$ ions from the titanate are required to release the latter, which then precipitate as $\mathrm{BaSO}_{4}$ upon contact with sulfate ions.

To sum up, the results obtained with the Sol 4 and Sol5 solutions emphasize the role of both sulfates and sodium in solution. The precipitation of $\mathrm{BaSO}_{4}$ shifts the equilibrium of the exchange process toward the incorporation of $\mathrm{Na}$ from the solution into the titanate powder in place of the Ba ions. Moreover, this process only occurs if cations able to exchange with (i.e. displace) the $\mathrm{Ba}$ ions from the titanate are present in the solution. These mechanisms are summarized by Eq. (6) above and Eqs (8) and (9) below.

$$
\begin{aligned}
& \overline{\mathrm{Ba}^{2+}}+\mathrm{SO}_{4}^{2-} \nrightarrow \mathrm{BaSO}_{4} \\
& \overline{\mathrm{Ba}^{2+}}+2 \mathrm{Na}^{+} \rightarrow \mathrm{Ba}^{2+}+\overline{2 \mathrm{Na}^{+}} \stackrel{\mathrm{SO}_{4}^{2-}}{\longrightarrow} \mathrm{BaSO}_{4}
\end{aligned}
$$

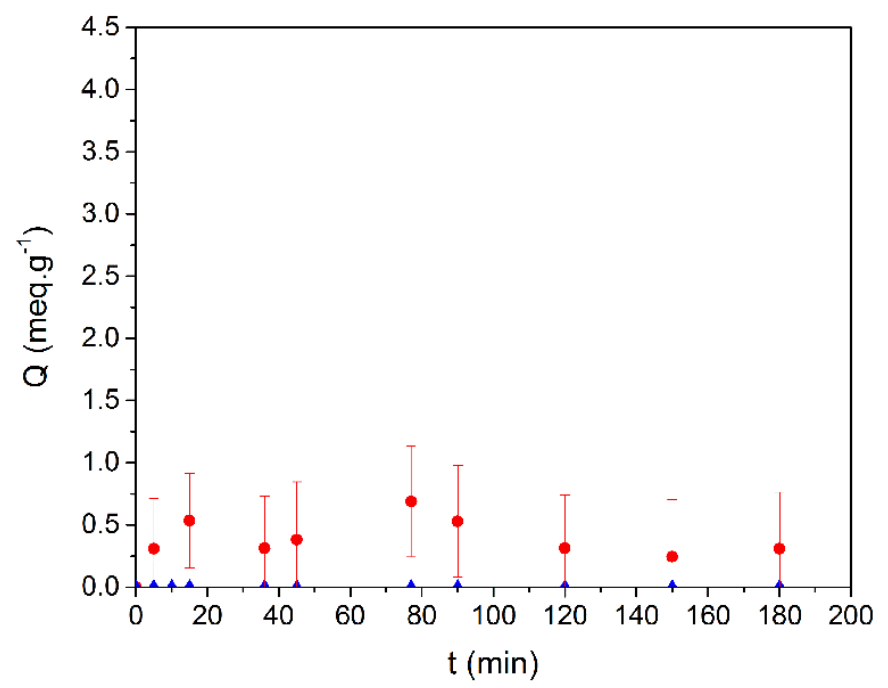

Fig. 6. Extraction behavior of the Ba-titanate in solutions containing tetrabutylammonium sulfate. Amounts (Q) of $\mathrm{SO}_{4}{ }^{2-}$ precipitated (red) and $\mathrm{Ba}^{2+}$ released (blue) versus contact time between the Ba-titanate and a $2.8 \times 10^{-2}$ $\mathrm{mol} \cdot \mathrm{L}^{-1}$ tetrabutylammonium sulfate solution (Sol5 in Table 2 ). 


\subsubsection{Behavior in a solution containing $\mathrm{Sr}$, $\mathrm{Na}$ and sulfate ions (Sol6)}

Similar to the results obtained with solution Sol4, Fig. 4B shows that sulfate ions precipitate in solution Sol6 after contact with the Ba-titanate and that no Ba ions are detected, implying again that the precipitate is $\mathrm{BaSO}_{4}$. The quantity of $\mathrm{Na}$ sorbed in the titanate (3.1 meq. $\left.\cdot \mathrm{g}^{-1}\right)$ is close to the amount of Ba that precipitates $\left(3.3 \mathrm{meq} \cdot \mathrm{g}^{-1}\right)$, which is consistent with $\mathrm{Ba} / \mathrm{Na}$ ion exchange (Eq. (6)).

Fig. 7 shows that the Sr concentration in solution drops rapidly upon contact with the Batitanate sorbent. After $5 \mathrm{~min}$ indeed, $0.14 \mathrm{meq} \cdot \mathrm{g}^{-1}$ of the $\mathrm{Sr}$ ions are extracted in Sol6, whereas in Sol2 (same composition but without sulfate ions) only $0.090 \mathrm{meq} \cdot \mathrm{g}^{-1}$ of the $\mathrm{Sr}$ ions are sorbed. In other words, the Sr uptake of the Ba-titanate material is higher when sulfate ions are present than when they are not, as $\mathrm{BaSO}_{4}$ precipitation complements the effects of ion exchange.

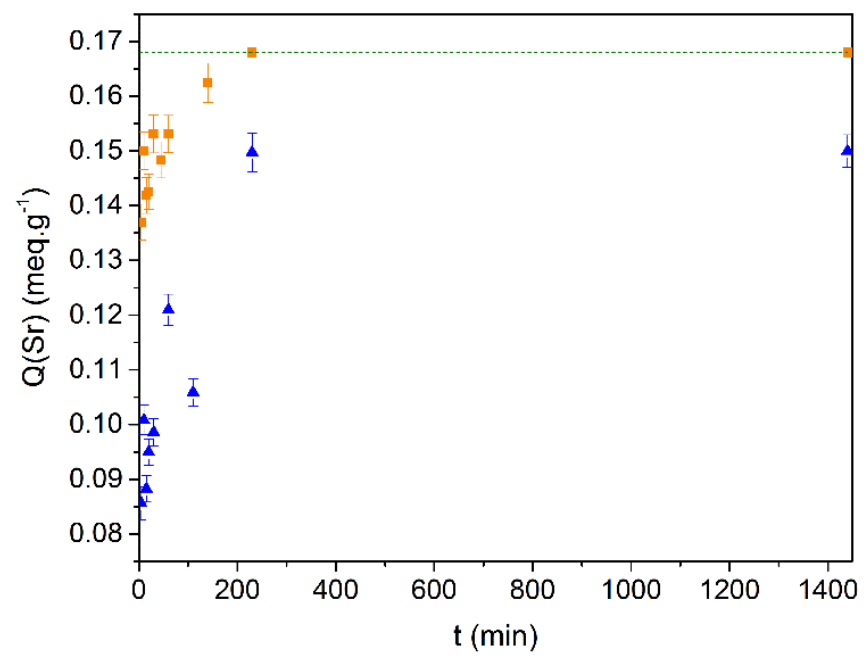

Fig. 7. Extraction behavior of the Ba-titanate in solutions containing $\mathrm{Sr}, \mathrm{Na}$ and sulfate ions. Sr extraction capacities versus time of the Ba-titanate in a solution containing sulfates (Sol6 in Table 2, orange) or not (Sol2, blue). The dotted line indicates the detection limit. 
These results lead to the following conclusions regarding the mechanisms of Sr extraction by the Ba-titanate in solutions containing sodium sulfate.

- The fact that the data points in Fig. 7 are not overlaid shows that the mechanism is not a pure $\mathrm{Ba} / \mathrm{Sr}$ ion exchange, for which the Sr extraction capacities in Sol6 and Sol2 (with and without sulfate ions) would be the same.

- The Sr ions may be extracted exclusively by coprecipitation. In this case, the amount of sulfate in the precipitates would equal the amount of $\mathrm{Na}$ in the solid after exchange with $\mathrm{Ba}$, and $\mathrm{Sr}$ would not participate with $\mathrm{Na}$ in the displacement of $\mathrm{Ba}$ ions from the titanate to the solution. Although Fig. $4 \mathrm{~B}$ shows that the amount of precipitated sulfate is slightly higher than the quantity of $\mathrm{Na}$ sorbed, the associated uncertainties mean that a pure coprecipitation mechanism cannot be ruled out.

- The alternative interpretation is that $\mathrm{Sr}$ is extracted via the coupled effects of coprecipitation as $\mathrm{BaSO}_{4}$ and $\mathrm{Ba} / \mathrm{Sr}$ ion exchange in the Ba-titanate.

In order to determine which of the latter two hypotheses is correct and quantify the proportions of coprecipitated and sorbed Sr, the Ba-titanate powder stirred in the Sol6 solution for $24 \mathrm{~h}$ was analyzed by XRD and a Rietveld refinement was performed.

The XRD pattern clearly identifies the $\mathrm{BaSO}_{4}$ phase (Fig. S5). The presence of $\mathrm{Sr}$ in the $\mathrm{BaSO}_{4}$ crystals is evidenced by the anisotropy of the corresponding diffraction lines. The refinements were difficult to achieve and the modelled structural data have a high $\mathrm{R}_{\mathrm{B}}$ factor (Table 4). The Sr contents of the $\mathrm{Ba}_{x} \mathrm{Sr}_{1-x} \mathrm{SO}_{4}$ phase deduced in this way should therefore be interpreted qualitatively rather than quantitatively.

\section{Table 4}

Cell parameters of the refined phases obtained by Rietveld analysis of the Ba-titanate X-ray diffractogram.

\begin{tabular}{lllllll}
\hline \multirow{2}{*}{ Compound } & $\begin{array}{l}\text { Space } \\
\text { group }\end{array}$ & $a(\AA)$ & $b(\AA)$ & $c(\AA)$ & $\begin{array}{c}\text { Cell } \\
\text { volume }\end{array}$ & $R_{B}$ \\
\hline
\end{tabular}




\begin{tabular}{ccccccc}
\hline & \multicolumn{3}{c}{$\left(\AA^{3}\right)$} \\
\hline $\mathrm{BaSO}_{4}$ & $\mathrm{Pnma}$ & $8.887 \pm 0.003$ & $5.439 \pm 0.002$ & $7.156 \pm 0.002$ & 345.86 & 16.68 \\
$\mathrm{Ba}_{x} \mathrm{Sr}_{1-x} \mathrm{SO}_{4}$ & $\mathrm{Pbnm}$ & $7.157 \pm 0.002$ & $8.843 \pm 0.002$ & $5.461 \pm 0.003$ & 345.58 & 18.34 \\
\hline
\end{tabular}

The formulation of the structure can be estimated by aligning the refined cell parameters (a, b, c) and the cell volume (V) with the data published by Sitepu and Zaidi [29] (Fig. 8). The average value of $x$ obtained is close to 0.99 , i.e. the composition of the mixed crystal is $\mathrm{Ba}_{0.99} \mathrm{Sr}_{0.01} \mathrm{SO}_{4}$.
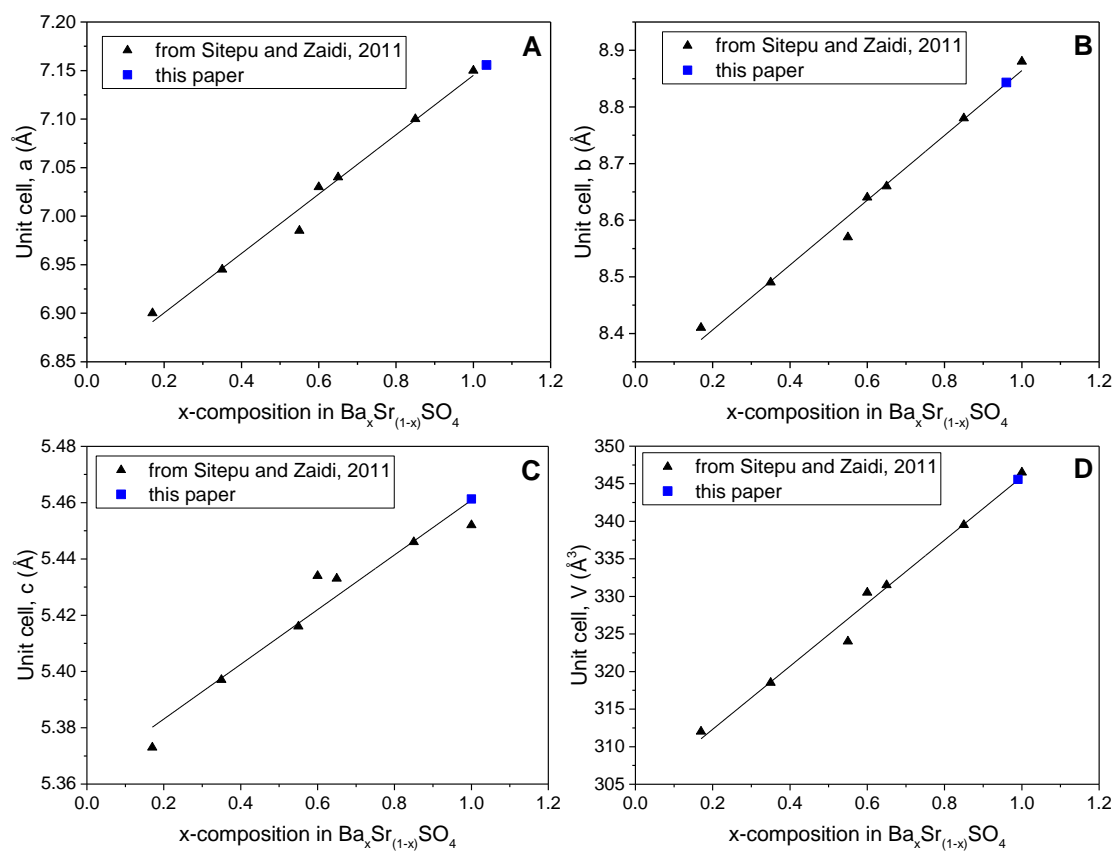

Fig. 8. Variation with $x$-composition of $\mathrm{Ba}_{x} \mathrm{Sr}_{1-x} \mathrm{SO}_{4}$ powders of $(\mathrm{A}-\mathrm{C})$ the refined unit-cell parameters along the $(A)$ a, (B) b-, (C) c-axis, and (D) the cell volume (adapted from Sitepu and Zaidi [29]).

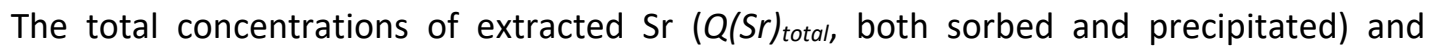
precipitated sulfate $\left(\mathrm{Q}\left(\mathrm{SO}_{4}\right)_{\text {precipitated }}\right)$ were calculated from measurements of the initial and final $\mathrm{Sr}$ and sulfate concentrations in the solution, giving $Q(\mathrm{Sr})_{\text {total }}=0.19 \mathrm{meq} \cdot \mathrm{g}^{-1}$ and $Q\left(\mathrm{SO}_{4}\right)_{\text {precipitated }}$ $=2.1 \mathrm{meq} \cdot \mathrm{g}^{-1}$. Given that the mixed-crystal structure is $\mathrm{Ba}_{0.99} \mathrm{Sr}_{0.01} \mathrm{SO}_{4}$, the $\mathrm{Sr}$ concentration that precipitates equals $1 \%$ of the molar concentration of the precipitated sulfate, or $0.021 \mathrm{meq} \cdot \mathrm{g}^{-1}$. 
The amount of $\mathrm{Sr}$ extracted by ion exchange is then $0.17 \mathrm{meq} \cdot \mathrm{g}^{-1}$ (from $Q(\mathrm{Sr})_{\text {ion exchange }}=$ $\left.Q(S r)_{\text {total }}-Q(S r)_{\text {coprecipitated }}\right)$. In other words, most of the Sr ions $(89 \%)$ are sorbed by exchange with the $\mathrm{Ba}$ ions of the titanate and only $11 \%$ coprecipitate. These results are similar to those reported by Avramenko et al. [31] for two Ba-silicotitanates with $\mathrm{K}_{\mathrm{d}} \mathrm{S}$ of $12000 \mathrm{~mL} \cdot \mathrm{g}^{-1}$ obtained under the same conditions as those used in the present study (i.e. $1 \mathrm{~g} \cdot \mathrm{L}^{-1}$ of sorbent in seawater). Assuming that the $\mathrm{Sr}$ and $\mathrm{Ba}$ were not leached by $\mathrm{HCl}$ from the finely dispersed precipitates of $\mathrm{BaSO}_{4}$, the authors deduced from the $\mathrm{HCl}$ treatment (total dissolution of the sorbents after sorption) that about $80 \%$ of $\mathrm{Sr}$ ions were entrapped in the sorbent by ionexchange whereas $20 \%$ were fixed by coprecipitation onto the $\mathrm{BaSO}_{4}$ phase formed on the surface.

\subsubsection{Behavior in a solution containing $\mathrm{Na}, \mathrm{Sr}$, Ca and sulfates (Sol7)}

The $\mathrm{Ba}$ ions still all precipitate when $\mathrm{Ca}$ ions $\left(1.4 \times 10^{-3} \mathrm{~mol} \cdot \mathrm{L}^{-1}\right)$ are added to the solution. Fig. $4 B$ shows indeed that the amount of sulfate extracted from the solution $\left(Q\left(\mathrm{SO}_{4}\right)=\right.$ $3.3 \mathrm{meq} \cdot \mathrm{g}^{-1}$ ) equals the initial amount of $\mathrm{Ba}$ in the solid. In solution Sol3 (same cations but without sulfate anions), less $\mathrm{Ba}$ is released (1.5 meq. $\mathrm{g}^{-1}$, see Fig. $\left.4 \mathrm{~A}\right)$. Moreover, the amount of Ca sorbed by the solid increases from $0.74 \mathrm{meq} \cdot \mathrm{g}^{-1}$ in Sol3 to $1.6 \mathrm{meq} \cdot \mathrm{g}^{-1}$ in solution Sol7. This means that the sulfate ions have the same effect on $\mathrm{Ca}$ as on $\mathrm{Na}$ ions, namely that the precipitation of $\mathrm{BaSO}_{4}$ shifts the exchange equilibrium toward the incorporation of the cations into the titanate in place of the $\mathrm{Ba}$ ions. However, the quantity of sorbed $\mathrm{Na}$ is lower (1.7 meq. $\mathrm{g}^{-1}$ ) in solution Sol7 (with Ca) than in Sol6 (3.1 meq $\cdot \mathrm{g}^{-1}$, without Ca), this difference being due to Ca sorption in Sol7. Therefore, even if the sulfate ions allow the sorption of different cations to replace $\mathrm{Ba}$ in the titanate, the relative quantities sorbed depend on the titanate's affinity for each of these cations. The relative selectivity of the material for different cations in solution is thus also important to consider. Indeed, Table 3 shows that in $\mathrm{Sol} 3$ ( $\mathrm{Ba} / \mathrm{Sr}, \mathrm{Ba} / \mathrm{Ca}$ 
and $\mathrm{Ba} / \mathrm{Na}$ exchanges only), the selectivity coefficient, $s K_{C a}^{S r}=1$ whereas in Sol7, $s K_{C a}^{S r}=60$. These results underline the importance of $\mathrm{Sr}$ coprecipitation with $\mathrm{BaSO}_{4}$ as it increases the selectivity of the material for Sr over Ca and thereby increases the decontamination factor.

\section{Conclusions}

A barium titanate material has been shown to be an effective and selective sorbent for the extraction of strontium from high-salinity effluents such as seawater. The mechanisms of strontium extraction in effluents containing sulfate ions are ion exchange of the Ba ions in the solid and then coprecipitation with barium sulfate on the surface of the titanate grains.

In solutions containing strontium, sodium, calcium and sulfate ions, the $\mathrm{Ba} / \mathrm{Sr}, \mathrm{Ba} / \mathrm{Na}$ and $\mathrm{Ba} / \mathrm{Ca}$ exchange reactions must all be considered along with the coprecipitation of strontium in $\mathrm{BaSO}_{4}$ precipitates (Eq. (10)):

$x \mathrm{Sr}^{2+}+\mathrm{Ba}^{2+}+(1+x) \mathrm{SO}_{4}^{2-} \rightarrow \mathrm{BaSr}_{x} \mathrm{SO}_{4(1+x)}$

From a kinetics viewpoint, the Ba-titanate material extracts strontium much faster in the presence of sulfate ions.

From a mechanistic viewpoint, $\mathrm{BaSO}_{4}$ precipitation occurs at the surface of the Ba-titanate grains rather than in solution. Furthermore, the $\mathrm{Ba}$ ions from the titanate all precipitate with sulfate ions in solution only if other cations ( $\mathrm{Na}$ or $\mathrm{Ca}$ ) are present to move the $\mathrm{Ba}$ ions from the titanate to the solution. $\mathrm{Sr}, \mathrm{Ca}$ and $\mathrm{Na}$ ions in solution all participate in the displacement of the Ba ions by ion exchange.

Although coprecipitation with $\mathrm{BaSO}_{4}$ occurs, the high $\mathrm{Sr}$ extraction capacity of this material is mainly the result of $\mathrm{Ba} / \mathrm{Sr}$ ion exchange. This behavior was explained here by the affinity of the Ba-titanate for Sr. However, $\mathrm{Sr}$ coprecipitation with $\mathrm{BaSO}_{4}$ is crucial in conferring a high 
selectivity for $\mathrm{Sr}$ over $\mathrm{Ca}$. Coprecipitation therefore contributes substantially to the high decontamination factors obtained.

\section{Acknowledgements}

This work was supported as part of the DEMETERRES project by CEA, AREVA and VEOLIA [grant NANR-11-RSNR-005]. The authors thank Veronique Testud and Renaud Domenger from the LMAC laboratory at CEA Marcoule for performing the compositional analyses by ICP-AES and the SEM measurements.

\section{References}

[1] IAEA, Radioactive Waste Management Profiles: A compilation of data from the waste management database, Vienna, 2000.

[2] V. Pacary, Etude des procédés de décontamination des effluents liquides radioactifs par coprécipitation : De la modélisation à la conception de nouveaux procédés, Institut national polytechnique de Lorraine, 2008. (In French).

[3] J. Flouret, Y. Barre, H. Muhr, E. Plasari, Design of an intensified coprecipitation reactor for the treatment of liquid radioactive wastes, Chem. Eng. Sci. 77 (2012) 176-183.

[4] Y. Barre, C. Lepeytre, G. Serve, private communication (2011).

[5] H. Mimura, Removal of radioactive caesium and strontium with zeolite, Nippon Kagaku Kaishi (1989) 621-627.

[6] G.B. Bengtsson, A.I. Bortun, V.V. Strelko, Strontium binding properties of inorganic adsorbents, J. Radioanal. Nucl. Chem.-Artic. 204 (1996) 75-82.

[7] A. Merceille, E. Weinzaepfel, Y. Barre, A. Grandjean, The sorption behaviour of synthetic sodium nonatitanate and zeolite $A$ for removing radioactive strontium from aqueous wastes, Sep. Purif. Technol. 96 (2012) 81-88.

[8] A. Sachse, A. Merceille, Y. Barre, A. Grandjean, F. Fajula, A. Galarneau, Macroporous LTAmonoliths for in-flow removal of radioactive strontium from aqueous effluents: Application to the case of Fukushima, Microporous Mesoporous Mater. 164 (2012) 251-258.

[9] T. Nakai, S. Wakabayashi, H. Mimura, Y. Niibori, Evaluation of Adsorption Properties for Cs and Sr Selective Adsorbents, in: Waste Management Conference, Phoenix, Arizona, USA, 2013. [10] D.M. Poojary, R.A. Cahill, A. Clearfield, Synthesis, crystal-structures, and ion-exchange properties of a novel porous titanosilicate, Chem. Mater. 6 (1994) 2364-2368.

[11] A. Clearfield, Structure and ion exchange properties of tunnel type titanium silicates, Solid State Sci. 3 (2001) 103-112.

[12] A.I. Bortun, L.N. Bortun, A. Clearfield, Evaluation of synthetic inorganic ion exchangers for cesium and strontium removal from contaminated groundwater and wastewater, Solvent Extr. Ion Exch. 15 (1997) 909-929.

[13] A. Clearfield, D.G. Medvedev, S. Kerlegon, T. Bosser, J.D. Burns, M. Jackson, Rates of exchange of Cs+ and Sr2+ for poorly crystalline sodium titanium silicate (CST) in nuclear waste systems, Solvent Extr. Ion Exch. 30 (2012) 229-243. 
[14] A. Tripathi, D.G. Medvedev, M. Nyman, A. Clearfield, Selectivity for Cs and Sr in Nbsubstituted titanosilicate with sitinakite topology, J. Solid State Chem. 175 (2003) 72-83.

[15] S. Chitra, S. Viswanathan, S.V.S. Rao, P.K. Sinha, Uptake of cesium and strontium by crystalline silicotitanates from radioactive wastes, J. Radioanal. Nucl. Chem. 287 (2011) 955960.

[16] S.F. Yates, P. Sylvester, Sodium Nonatitanate: a Highly Selective Inorganic Ion Exchanger for Strontium, Sep. Sci. Technol. 36 (2001) 867-883.

[17] A. Clearfield, J. Lehto, Preparation, structure, and ion-exchange properties of Na4Ti9O20 . xH2O, J. Solid State Chem. 73 (1988) 98-106.

[18] J. Lehto, L. Brodkin, R. Harjula, SrTreat - A highly effective ion exchanger for the removal of radioactive strontium from nuclear waste solutions, Radioactive Waste Management and Environmental Remediation, 1997.

[19] J. Lehto, L. Brodkin, R. Harjula, E. Tusa, Separation of radioactive strontium from alkaline nuclear waste solutions with the highly effective ion exchanger SrTreat, Nucl. Technol. 127 (1999) 81-87.

[20] P. Sylvester, T. Möller, T.W. Adams, Improved separation methods for the recovery of 82Sr from irradiated targets, Appl. Radiat. Isot. 64 (2006) 422-430.

[21] D.V. Marinin, G.N. Brown, Studies of sorbent/ion-exchange materials for the removal of radioactive strontium from liquid radioactive waste and high hardness groundwaters, Waste Manage. 20 (2000) 545-553.

[22] T. Kubota, S. Fukutani, T. Ohta, Y. Mahara, Removal of radioactive cesium, strontium, and iodine from natural waters using bentonite, zeolite, and activated carbon, J. Radioanal. Nucl. Chem. 296 (2013) 981-984.

[23] A.M. Egorin, T.A. Sokolnitskaya, M.V. Tutov, E.A. Tokar', M.Y. Matveikin, V.A. Avramenko, Composite selective sorbents for sea water decontamination from cesium and strontium radionuclides, Dokl. Phys. Chem. 460 (2015) 10-14.

[24] K.W. Kim, K.Y. Lee, E.H. Lee, Y. Baek, D.Y. Chung, J.K. Moon, A concept for an emergency countermeasure against radioactive wastewater generated in severe nuclear accidents like the Fukushima Daiichi disaster, Nucl. Technol. 193 (2016) 318-329.

[25] E.A. Behrens, P. Sylvester, A. Clearfield, Assessment of a sodium nonatitanate and pharmacosiderite-type ion exchangers for strontium and cesium removal from DOE waste simulants, Environ. Sci. Technol. 32 (1998) 101-107.

[26] G.M. Graziano, Synthesis, Characterization, and ion exchange properties of a sodium nonatitanate, Na4Ti9O20.xH2O, Texas A\&M University, 1998, p. 87.

[27] A. Merceille, E. Weinzaepfel, Y. Barre, A. Grandjean, Effect of the synthesis temperature of sodium nonatitanate on batch kinetics of strontium-ion adsorption from aqueous solution, Adsorption 17 (2011) 967-975.

[28] E. Goldish, X-Ray Diffraction Analysis of Barium-Strontium Sulfate (Barite-Celestite) Solid Solutions, Powder Diffr. 4 (1989) 214-216.

[29] H. Sitepu, S.R. Zaidi, Structural refinement of BaxSr1-xSO4 using X-ray powder diffraction data, Adv. X-ray Anal. 54 (2011) 1-8.

[30] H.S. Sherry, H.F. Walton, The ion-exchange properties of zeolites. II. Ion exchange in the synthetic zeolite Linde 4A, J. Phys. Chem. 71 (1967) 1457-1465.

[31] V.A. Avramenko, V.V. Zheleznov, E.V. Kaplun, T.A. Sokol'nitskaya, A.A. Yukhkam, Sorption Recovery of Strontium from Seawater, Radiochemistry 43 (2001) 433-436. 


\section{Supplementary information}

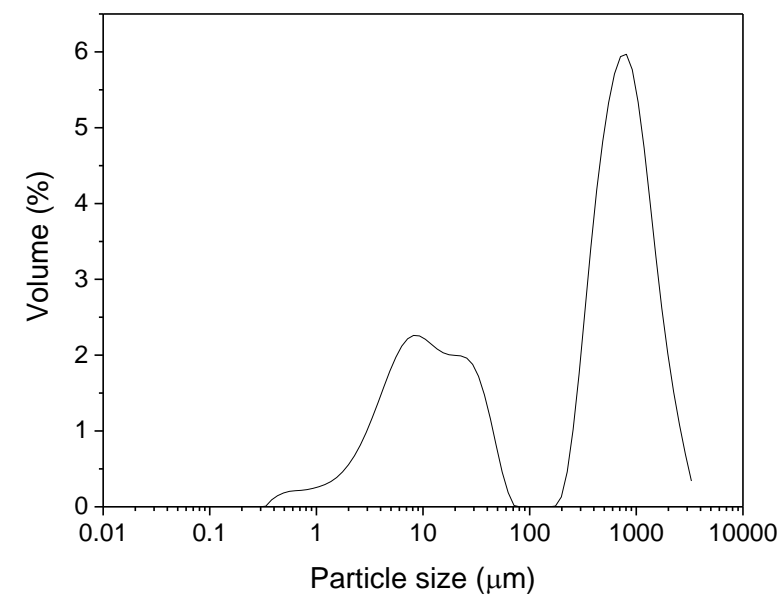

Fig. S1: Particle size distribution of the Ba-titanate

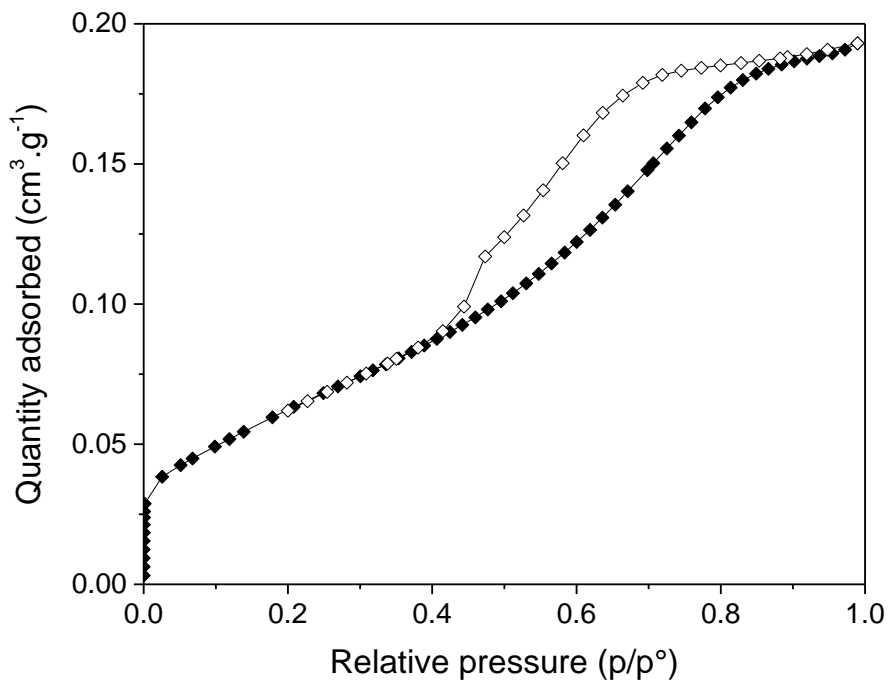

Fig. S2: Nitrogen adsorption (full symbols)-desorption (empty symbols) isotherms at $77 \mathrm{~K}$ of the synthesized Batitanate 

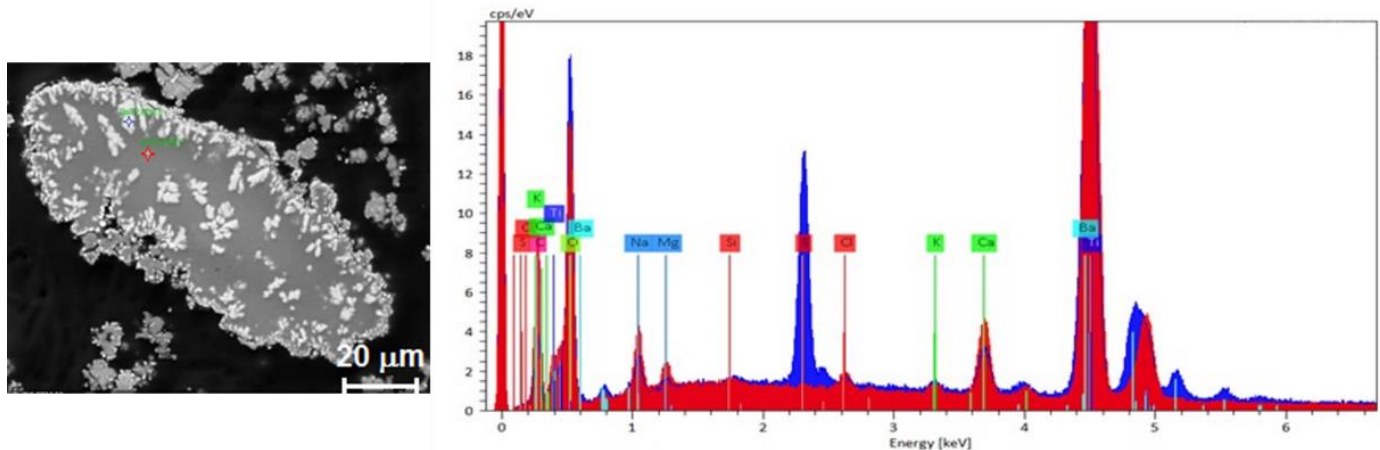

Fig. S3: EDX spectra of a pointing in the grey titanate phase (red spectrum) and a pointing in the white phase (blue spectrum)

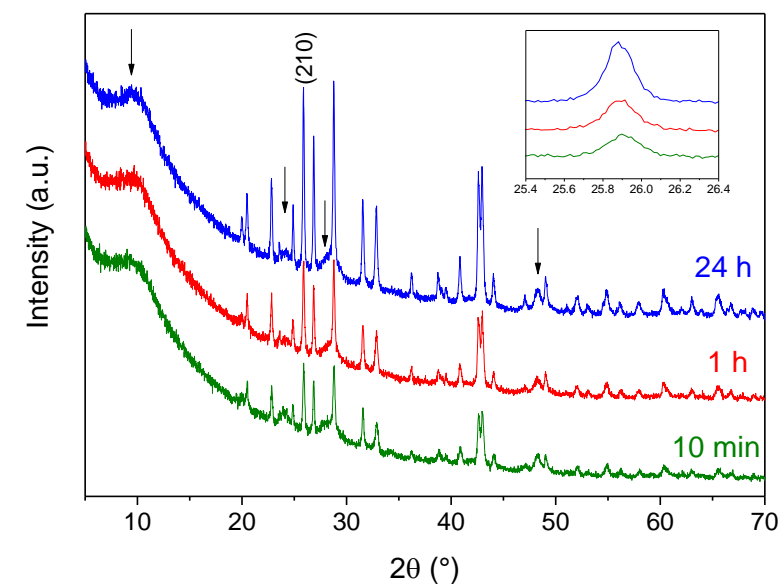

Fig. S4: X-ray diffractogram of the barium titanate after $10 \mathrm{~min}, 1 \mathrm{~h}$ and $24 \mathrm{~h}$ contact with a $\mathrm{Na}_{2} \mathrm{SO}_{4}$ solution ([ $\mathrm{SO}_{4}{ }^{2-}$ ] $\left.=2.8 \times 10^{-2} \mathrm{~mol} \cdot \mathrm{L}^{-1}\right)$. The inset graph is a zoom of the selected peak (210) for $\mathrm{BaSO}_{4}$ crystallite size estimation. The arrows indicate the titanate peaks.

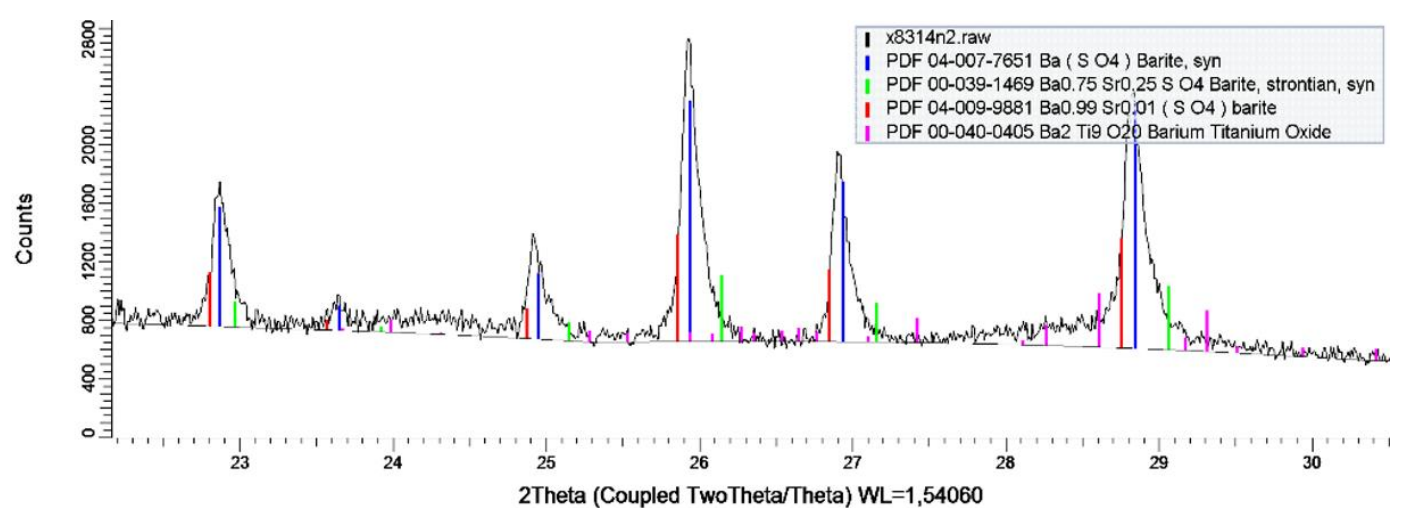

Fig. S5: X-ray diffractogram of the Ba-titanate after contact with a solution containing $\mathrm{Na}$, Sr and sulfates (Sol6). The presence of $\mathrm{Sr}$ in the $\mathrm{BaSO}_{4}$ crystals is evidenced by the X-ray diffraction lines anisotropy of $\mathrm{BaSO}_{4}$. 